\title{
Geospatial Assessment of the Consumption and Absorption of Residential and Educational Land Uses of Zaria and Sabon Gari Area of Kaduna State, Nigeria
}

\author{
Sule J. O. ${ }^{1,}$, Ojigi L. M. ${ }^{2}$, Adewuyi T. O. ${ }^{3}$, Azua S. ${ }^{1}$, Aliyu A. O. ${ }^{1}$ and \\ Akomolafe E. O. ${ }^{1}$ \\ ${ }^{1}$ Department of Geomatics, Ahmadu Bello University - Zaria, Kaduna State, Nigeria \\ ${ }^{2}$ National Space Research and Development Agency, Nigeria \\ ${ }^{3}$ Nigerian Defence Academy, Faculty of Art and Social Science, Department of Geography, Kaduna, Nigeria \\ Corresponding Author:*suleiman.jimoh@gmail.com
}

https://doi.org/10.36263/nijest.2021.02.0299

\begin{abstract}
Human variables such as population increase and distribution, as well as economic expansion, have a strong impact on land usage. Zaria and Sabon Gari local government areas are endowed with various types of institutions that attract people from far and near to its space for studies and employments. This in turn leads to increase in population growth and the expansion of residential land use (LU). Thus, this study assessed the Land Consumption Rate (LCR) and Land Absorption Coefficient (LAC) of the residential and educational LUs using geospatial technique. The study analyzed Landsat imagery of 1987, 1999, 2006, and 2018. The study utilized a combination of quantitative (pixel-based) and qualitative (digitizing) methods of image classification for classifying the residential and educational LUs and biophysical covers. Quantitative assessment of the $L U$ dynamics was achieved by the post-classification computation of LU dynamics, LCR, and LAC. The results revealed that residential LU occupied an area of 2594.25ha in 1987, 2815.15ha in 1999, 4042.54ha in 2006, and 8033.19ha in 2018. In the same vein, the educational LU occupied area of 2623.41 ha in 1987, 2991.87ha in 1999, 3021.10ha in 2006, and 3093.75ha in 2018. The LCR values for residential LU were $0.555 \%, 0.468 \%, 0.579 \%$, and $0.803 \%$ for the years 1987 , 1999, 2006, and 2018 respectively. The LCR reduced from 1987 to 1999 and then increased from 1999 to 2018. The LAC values for the residential LU increased across the period of the study. The study concluded that the exploitation of the new lands for residential and educational LUs could be as a result of the demographic and institutional drivers of $L U$. The study suggested that the urban planning authority should develop planning measures that will regulate the already crowded residential $L U$ in the study area.
\end{abstract}

Keywords: Educational, Land absorption coefficient, Land coefficient ratio, Land use, Residential

\subsection{Introduction}

Human population increase, rising resource use by human cultures, and developments in technology and socio-political structure are all driving rapid changes in the Earth's ecosystem (Karsidi, 2004). One of the consequences of this transformation is land use dynamics. Skole and Tucker (1993) noted that Human variables such as population increase and distribution, as well as economic expansion, have a strong impact on land usage. Nowadays, human attachment to land includes more complicated functions such as industry and tourism, in addition to habitat and living space (Mather, 1986). Consequently, fast replacement of land cover (LC) patterns by diverse land use (LU) patterns is seen globally (Lambin and Geist, 2001).

The preference for economic expansion above ecological sustainability resulted in the depletion of vast natural resources such as forests, water bodies, minerals, soil, and so on, resulting in severe and quick shifts in LULC patterns (Beckerman, 1992). The government's development plans, whether for 
infrastructural growth or economic stability, have a significant impact in the alteration of an area's LULC (Prasad et al., 2010). Therefore, the LULC information is important for quantitatively measuring land conversion and modification of a region. The terms Land Use and Land Cover (LULC) are related and technically not the same. Foody and Atkinson (2002); Aspinall and Hill (2008) defined land cover as the surface cover on the ground, whether vegetation, urban infrastructure, water, bare soil or other. On the other hand, land use is defined as (deBie et al., 1996) operations on land, carried out by humans, with the intention to obtain products and/or benefits through using land resources.

In the recent decade, land transformation has emerged as a significant study subject (Turner et al., 2007; Turner and Robbins, 2008). The goal of land change science is to understand the biophysical and human causes of land use and land cover change, as well as the patterns and dynamics of land use and land cover that impact the structure and function of the Earth system (Rindfuss et al., 2004). Remote sensing (RS) and Geographic Information System (GIS) technologies only detect the nature, extent, and pace of LULC changes on the landscape; they do not explain the underlying causes of LULC dynamics on the landscape (Wondie et al., 2011; Kindu et al., 2013). The RS technology has evolved into an essential tool for stakeholders to use in evaluating and anticipating LULC as it occurs throughout time (Aliyu et al., 2020). Previous studies have been conducted to assess land use over time in various developing countries across the world (Rimal et al., 2020). Land use change dynamics was carried out by Anwar (2002); land use dynamics and demographic change by Ouedraogo (2010); Tsvetkova (2014) analyzed the spatial and temporal dynamics of land use. Verburg (2000) explored the spatial and temporal dynamics of land use. These studies focused on the LAC of built-up as a whole while this present study focused specifically on the residential and educational LUs.

Zaria and Sabon Gari LGAs of Kaduna state are endowed with numerous types of institutions ranging from State and Federal Universities, Polytechnic, College of Education, School of Aviation Technology, College of Leather Research, Nigerian Institute of Transport Technology (NITT), Nigerian Military School (NMS), Nigerian Depot, Army Corps of Engineers, School of Nigerian Military Police, Zaria Academy. These institutional must have attracted people from far and near to want to come to Zaria and Sabon Gari LGAs for study and for employment. This in turn triggered the demand and expansion of residential LU. Most of the literature consulted did not address specifically the LCR and LAC of residential and educational land uses of the Zaria and Sabon Gari LGAs. Therefore, this study aimed at assessing the consumption and absorption of residential and educational land uses of Zaria and Sabon Gari LGAs of Kaduna state in Nigeria to ascertain the consumption rate of the uses. The study was achieved by identifying the residential and educational land uses through classifying the datasets; and the computation of the consumption rate and absorption coefficient of the LUs. This enabled the study to understand the spatio-temporal consumption rate and absorption coefficient of the residential and educational land uses.

\subsection{Study area description}

Zaria and Sabon Gari LGAs of Kaduna state are situated between latitudes $11^{\circ} 00^{\prime}$ and $11^{\circ} 30^{\prime}$ north and longitudes $7^{\circ} 30^{\prime}$ to $7^{\circ} 45^{\prime}$ east. They are bounded in the West by Giwa, in the north, east and south by Kudan, Soba and Igabi LGAs respectively. They occupied an area of 54,577.78ha. The population for Zaria and Sabon Gari LGAs in 1991 is 284318 and 224067, and 549400 and 393300 in 2006 (NPC, 2006). It has minimum and maximum elevations of $576 \mathrm{~m}$ and $800 \mathrm{~m}$ above mean sea level. The land uses in Zaria and Sabon Gari LGAs are residential, agricultural, educational, commercial, industrial, health, and security. 
(a)

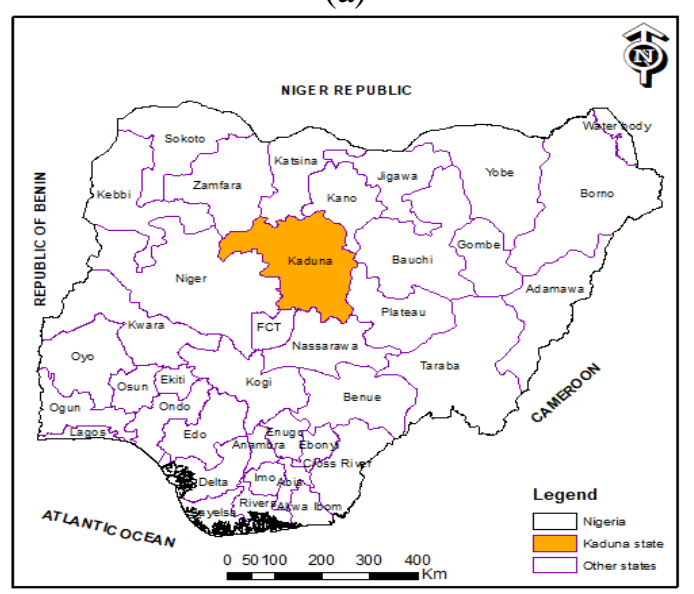

(b)

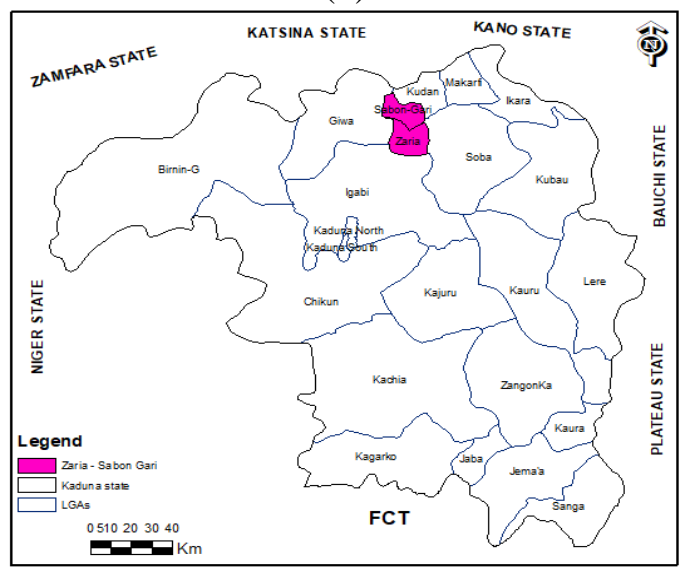

(c)

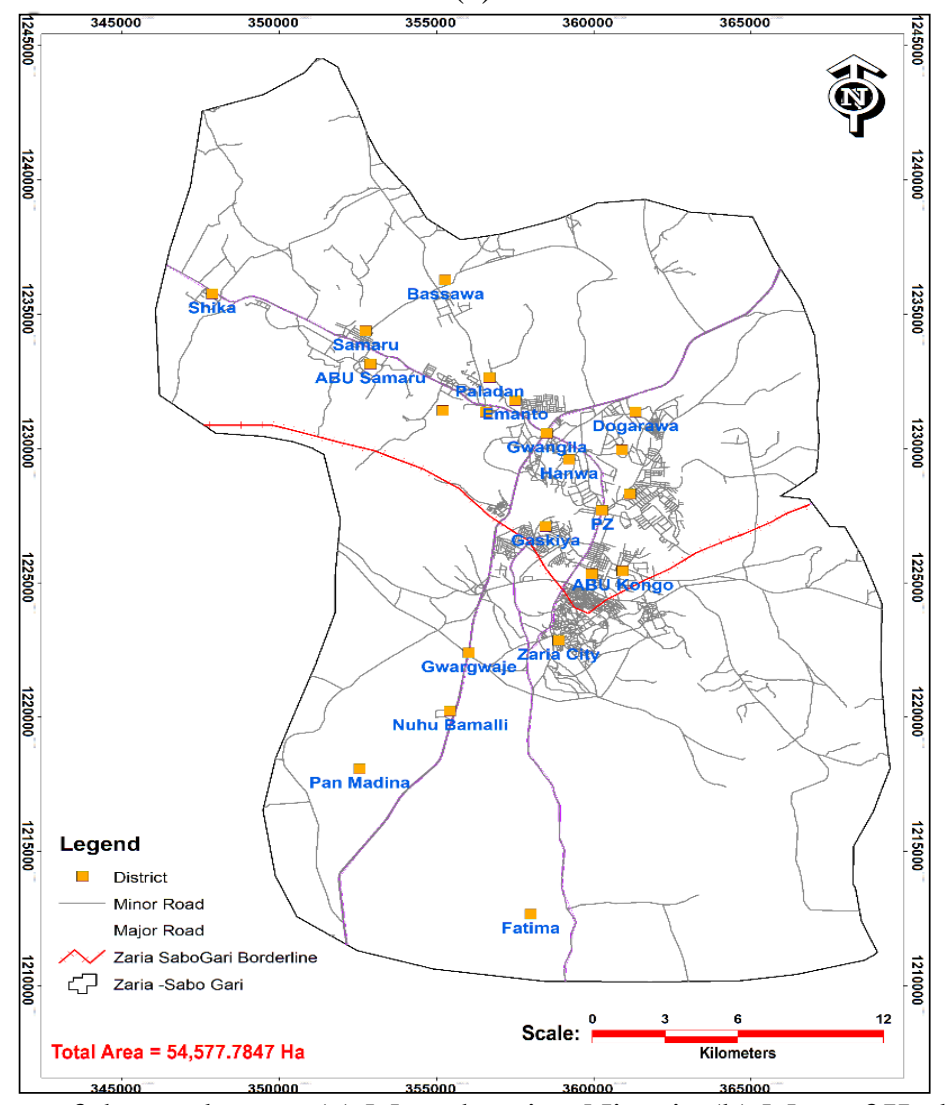

Figure 1: Inset map of the study area (a) Map showing Nigeria (b) Map of Kaduna state (c) Map showing Zaria and Sabon Gari LGAs.

Adapted from (Global Administrative Digital Map, 2018).

\subsection{Methodology}

The methods adopted for this study include data collection, processing and analysis of the land uses. These have been summarized in Figure 2. 


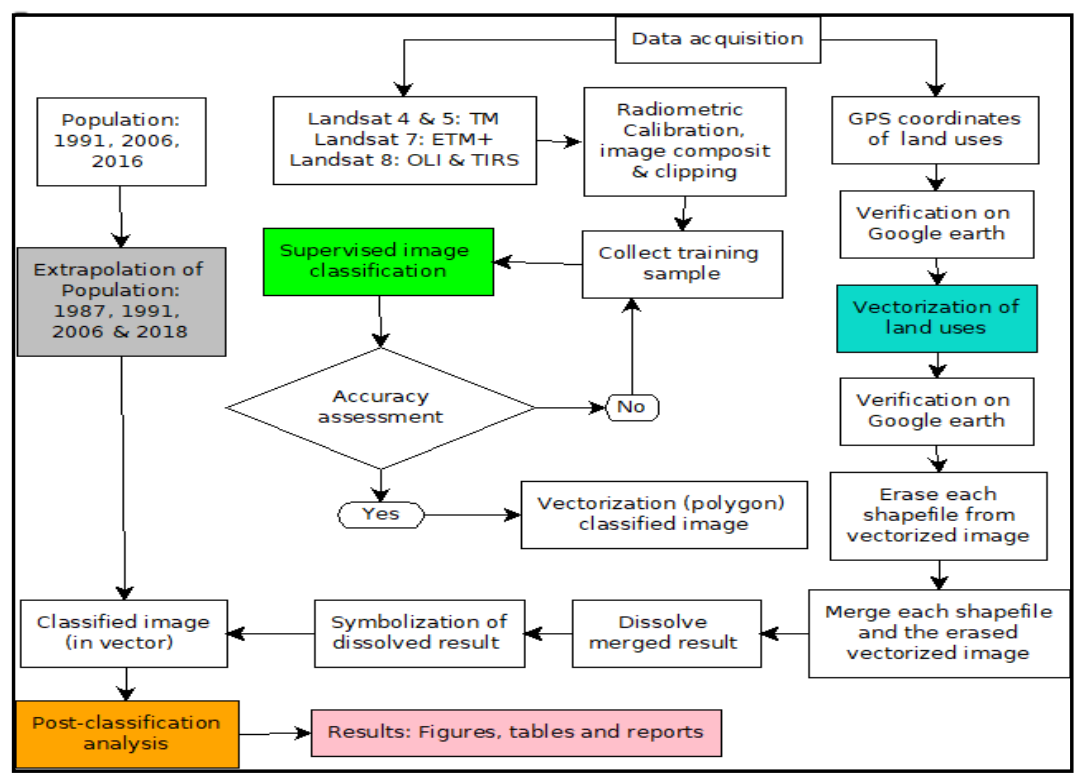

Figure 2: Workflow diagram of the study

\subsection{Datasets and sources}

The study acquired GPS coordinates of educational and other LUs (commercial, health, industrial etc.) with a Garmin $78 \mathrm{~S}$ handheld GPS receiver. The study also acquired multispectral optical remotely sensed datasets in the dry season (November and January) to avoid exaggerating the study area with vegetation. Also, comparative studies are best carried out in near anniversary months. The images were cloud-free in path/row of 189/52. The images were registered to Projected Coordinate System WGS 84, UTM Zone-32N. except for the Landsat 8. The details of the various datasets and their sources are outlined in Table 1 and a sample of the GPS coordinates is shown in Table 2.

Table 1: Datasets and their characteristics

\begin{tabular}{|c|c|c|c|c|c|}
\hline $\mathrm{S} / \mathrm{N}$ & Data Type & Date & Resolution & Source & Purpose \\
\hline 1. & GPS coordinates & $15 / 3 / 2018$ & & Field & Identify LUs \\
\hline 2. & Landsat 5 TM & $\begin{array}{l}11 / 01 / 1987 \text { and } \\
12 / 02 / 1999\end{array}$ & $30 \mathrm{~m}$ & http://www.glovis.usgs.gov & $\begin{array}{l}\text { LULC } \\
\text { classification }\end{array}$ \\
\hline 3. & Landsat 7 ETM+ & $13 / 01 / 2006$ & $30 \mathrm{~m}$ & http://www.glovis.usgs.gov & $\begin{array}{l}\text { LULC } \\
\text { classification }\end{array}$ \\
\hline 4. & Landsat 8 OLI & $17 / 02 / 2018$ & $30 \mathrm{~m}$ & http://www.glovis.usgs.gov & $\begin{array}{l}\text { LULC } \\
\text { classification }\end{array}$ \\
\hline 5. & SPOT 5 & 2013 & $5 \mathrm{~m}$ & OSGOF, Nigeria & Ancillary data \\
\hline 6. & SRTM DEM & 2003 & 30 & http://www.glovis.usgs.gov & $\begin{array}{l}\text { Topography and } \\
\text { draping }\end{array}$ \\
\hline 7. & Google Earth Pro & 02/01/2018 & $1 \mathrm{~m}$ & http://www.googleearth.com & $\begin{array}{l}\text { Visual } \\
\text { interpretation }\end{array}$ \\
\hline 8. & $\begin{array}{l}\text { Administrative } \\
\text { map }\end{array}$ & 02018 & Nil & http://www.gadm.org & $\begin{array}{l}\text { Extraction of } \\
\text { study area }\end{array}$ \\
\hline 9. & Population data & 1991 and 2006 & Nil & $\begin{array}{l}\text { National Population } \\
\text { Commission }\end{array}$ & For LCR/LAC \\
\hline
\end{tabular}

Table 2: Sample of GPS coordinates of educational LU in excel file

\begin{tabular}{llllll}
\hline S/N & Easting $(\mathrm{m})$ & Northing $(\mathrm{m})$ & $\begin{array}{l}\text { Height } \\
(\mathrm{m})\end{array}$ & Code & Remarks \\
\hline 1. & 343230 & 1219744 & 661 & EDU & L.G.E.A. RAFIN YASHI \\
2. & 343622 & 1232489 & 685 & EDU & LGEA PRY SCH./CLINIC BIJIMI GIWA LGA \\
3. & 344435 & 1233322 & 696 & EDU & NBC PRIMARY SCH. TUDUN BIYE \\
4. & 344547 & 1220503 & 674 & EDU & L.G.E.A GIDAN ZAKI ZARIA \\
5. & 344632 & 1218784 & 649 & EDU & L.G.E.A. ANGWAN MALAM SANI PRIMARY SCH. \\
6. & 345411 & 1222502 & 692 & EDU & L.G.E.A. PRIMARY SCH. KAFIN MARDANNI \\
7. & 346027 & 1224205 & 692 & EDU & L.G.E.A. PRIMARY SCH. \\
8. & 346203 & 1227284 & 712 & EDU & L.G.E.A. RAFIN YASHI II \\
\hline
\end{tabular}




\subsection{Data processing}

\subsubsection{Radiometric calibration}

The images were radiometrically normalized to spectral radiance. The scale of the calibration was to at-sensor spectral radiance. This was to correct for the difference in acquisition time and date of the sensors due to sun-earth distance at the time the sensors were orbiting the earth. The algorithms for the radiometric calibration are shown in Equations 1 and 2.

1. Conversion of DN to radiance (for TM and ETM+):

$\left.L_{\lambda}=\frac{L_{M A X \lambda}-L_{\mathrm{MIN} \lambda}}{Q_{\text {calmax }}-Q_{\text {calmin }}}\left(Q_{C A L}-Q_{C A L M I N}\right)+L_{M I N \lambda}\right)$

2. Conversion of DN to Radiance (for OLI and TIRS):

$L_{\lambda}=M_{L} \times Q_{C A L}+A_{L}$

Where: $\mathrm{L}_{\lambda}=$ spectral radiance at the sensor's aperture; $\mathrm{Q}_{\mathrm{CAL}}=$ Quantized calibrated pixel value $(\mathrm{DN})$; $\mathrm{Q}_{\mathrm{CALMIN}}=$ Maximum quantized pixel value (corresponding to $\mathrm{L}_{\mathrm{MAX} \lambda}$ ) in $\mathrm{DN}=255 ; \mathrm{L}_{\mathrm{MIN} \lambda}=$ spectral radiance that is scaled to $\mathrm{Q}_{\text {CALMAX }}(\mathrm{W} . \mathrm{m}-1$. ster-1. $\mu \mathrm{m}-1) ; \mathrm{L}_{\mathrm{MAX} \lambda}=$ Spectral radiance that is scale to $\mathrm{Q}_{\text {calmin }}$ (W. m-1. ster-1. $\mu \mathrm{m}-1$ ); $\mathrm{M}_{\mathrm{L}}=$ Band-specific multiplicative rescaling factor from the metadata (RADIANCE_MULT_BAND_x, where $\mathrm{x}$ is the band number). $\mathrm{A}_{\mathrm{L}}=$ Band-specific additive rescaling factor from the metadata (RADIANCE_MULT_BAND_x, where $\mathrm{x}$ is the band number) (United States Geological Survey, 2013). This operation was carried out in ArcMap v10.5.

\subsubsection{Image composite and clipping}

The bands that were stacked for the Landsat TM and ETM+ images are band 1, 2, 3, 4, 5 and 7. Also, band 2, 3, 4, 5, 6, and 7 were stacked for Landsat 8 for color display. Then, the images were clipped using the boundary shapefile in ArcMap v10.5.

\subsubsection{Integrated approach for image classification}

Due to the coarse resolution of the Landsat images, it is usually thorny to carry-out a successful pixelbased classification, especially when certain land uses are to classify distinctly from built-up area. More so, object-based image classification method would have been ideal if a high-resolution imagery were available for the study. GISGeography (2021) explains that object-based image technique firstly, segments an image into groups of similar pixels into vector objects. Secondly, it classifies those objects using their shape, size, spatial and spectral properties. Therefore, to successfully classify the residential and educational LUs distinctly with other land uses and biophysical covers, an integrated method that combines the conventional image classification method (supervised) and qualitative technique (vectorization) was used for this study (see Figure 2).

Training samples were collected from the images and converted into spectral signatures for two classes only: built-up area and biophysical cover (see Table 3). Then, supervised image classification was carried out on the images and the Maximum Likelihood Classifier (MLC) was used as a parametric decision rule. It assumes that the probabilities are equal for all classes and that the input bands have normal distribution (Ongsomwang, 2007). The Landsat images were then classified into two (2) classes, namely: built-up and biophysical cover for the pixel-based classification. After this, a confusion matrix was generated for the classified images to know whether to accept the classification or otherwise.

Table 3: Description of the land covers used for supervised classification

\begin{tabular}{llll}
\hline S/N & Training sample & Color assign & Description \\
\hline 1 & Built-up & Red & $\begin{array}{l}\text { All developed areas e.g., residential, educational, industrial, health, } \\
\text { commercial areas etc. } \\
\text { Land consisting of cultivated, uncultivated, waterbody, riparian and } \\
\text { rock-outcrop }\end{array}$ \\
\hline Biophysical cover & Grey & Source: Modified after (Anderson, 2008).
\end{tabular}

In incorporating the qualitative technique, the classified images for 1987, 1999, 2006, and 2018 were converted to polygon. Then the GPS coordinates of the educational and other LUs were then plotted 
on Google earth and were polygonised (see Figure 3). They were then exported to ArcMap, where they were overlaid on each Landsat image (unclassified) in ArcMap to verify if such land use existed in the year 1987, 1999, 2006 and 2018 respectively. Otherwise, the non-existent shapefiles were deleted. This operation was possible with the aid of the elements of image interpretation and a comprehensive familiarity of the study area by the image analyst.

Furthermore, after assigning the correct shapefile of each land use to their corresponding image, a new field was created named "GRIDCODE" in the attribute table of each shapefile, an integer number was assigned to each shapefile, namely: educational $=3$, other LUs $=4$. This order was necessary because the already classified images have classes in this order, namely: built-up (now residential) $=1$ and biophysical cover $=3$.

After this, the LU shapefiles of 1987 image was then erased from the "polygonized-classified" image (i.e. the converted classified image to polygon) of 1987 one after the other. This was repeated for the classified images of 1999, 2006 and 2018 respectively. This was done using the erase tool in ArcMap v10.5. For merging operation, each shapefile and each erased shapefile of each year were merged using the merge tool in ArcMap v10.5. Each merged shapefiles of 1987, 1999, 2006 and 2018 was then dissolve to individual features based on specified attributes. The "GRIDCODE attribute field was selected for dissolving. Finally, each land use and the biophysical cover class was cartographically symbolized.

The final LULC cover classes were: residential (buildings for residents), educational (buildings for purpose of learning e.g., schools, colleges, polytechnic etc.), other LUs (buildings for purpose of commercial, health, industrial, religious, security) and biophysical cover (see Table 3).

(a)

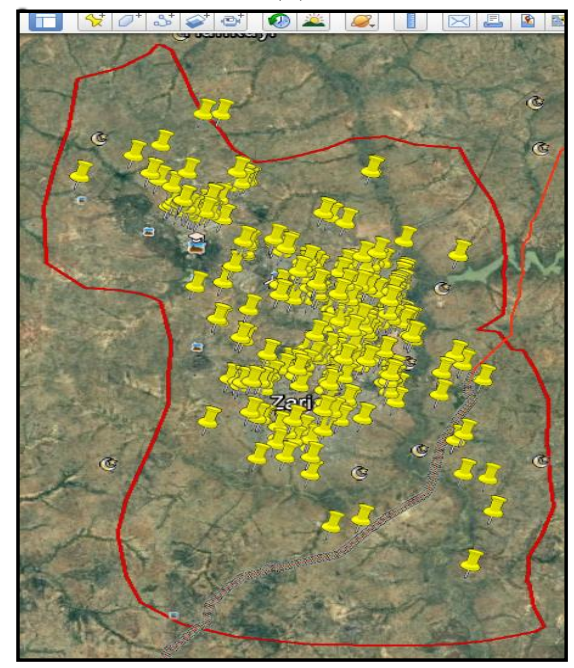

(b)

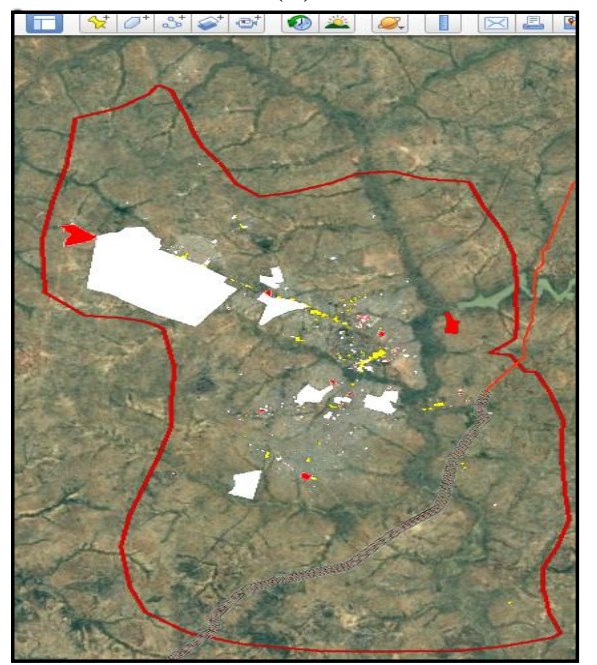

Figure 3: (a) The GPS coordinates of educational land use and (b) Digitized educational land use in Google Earth software.

\subsection{Data analysis}

\subsubsection{Post-classification analysis}

Post-classification analysis such area distribution, area change and percentage area were computed. The area change was carried out for the between the earlier and recent LULC maps: 1987-1999, 1999-2006, 2006-2018 and 1987-2018 respectively. The area distribution and area change computations were one the requirements of computing the LCR and LAC.

\subsubsection{Land absorption coefficient/land consumption rate}

LCR measures the compactness that reflects the progressive spatial growth of a city. High LCR value indicates crowdedness and low LCR value indicates free spaces, whereas LAC measures how much additional urban land is consumed for each unit growth in population. It shows how new land is being 
sought for development and how the population is spreading to the outermost of the city or sprawling (Laxmikant et al., 2012).

The computations were based on the assumption that land consumption grows with population growth, resulting in increase in urban expansion (Laxmikant et al., 2012). The computation requires area of a land use in hectares of a year and the corresponding population of that year. The mathematical expressions for the LCR and LAC are shown in Equations 3 and 4 (Yeates and Garner, 1976):

$$
\begin{aligned}
& L C R(\%)=\frac{\text { City Extension Hectares }(A)}{\text { Population }(P)} \\
& L A C=\frac{\text { Area Extent of LU for the recent year }\left(A_{2}\right)-\text { Area Extent of LU for the early year }\left(A_{1}\right)}{\text { Population for the recent year }\left(P_{2}\right)-\text { Population for the early year }\left(P_{1}\right)}
\end{aligned}
$$

The population size was estimated using the projected population expression (Equation 5) with the established census data of 1991 and 2006 and the 3.0\% growth (NPC, 2006) rate for the study area.

$\operatorname{Pop}_{(\text {projected })}=\operatorname{Pop}_{(\text {known })} \times\left(1+\frac{\text { Annual Growth Rate }}{100}\right)^{T}$

Where Pop is population and $T$ is time interval between initial year and projected year

\subsection{Results and Discussion}

\subsection{LC distribution}

The LC maps of Zaria and Sabon Gari from 1987, 1999, 2006 and 2018 are presented in Figures 4a $4 \mathrm{~d}$. The residential and the educational LUs are shown in golden and red colours. The large area of educational that is common to all the images is Ahmadu Bello University Zaria, which was in existence since 1964.

The area distributions, area percentage, and change in area percentage are presented in Figure 5 and Table 4. The results revealed that the residential LU occupied an area of 2594.25 ha (4.76\%) in 1987, 2815.15 ha $(5.16 \%)$ in $1999,4042.54$ ha $(7.41 \%)$ in 2006 , and 8033.19 ha $(14.69 \%)$ in 2018. In the same vein, the educational LU occupied area of 2623.41 ha $(4.81 \%)$ in $1987,2991.87$ ha $(5.48 \%)$ in $1999,3021.10$ ha $(5.53 \%)$ in 2006, and 3093.75 ha (5.66\%) in 2018. Other LUs had area of 580.53 ha $(1.06 \%), 682.14$ ha $(1.25 \%), 731.41$ ha $(1.34 \%)$, and 876.59 ha $(1.60 \%)$ in the year 1987, 1999, 2006, and 2018 respectively. It implied from the result that both residential and educational LUs increased overtime. For the biophysical cover, the area values decreased overtime. This implied that the LUs gained from the biophysical cover as a function of the drivers of LU conversion and modification such as demographic, institutional, socio-economic, political factors that influence LU decision making. 
(a)

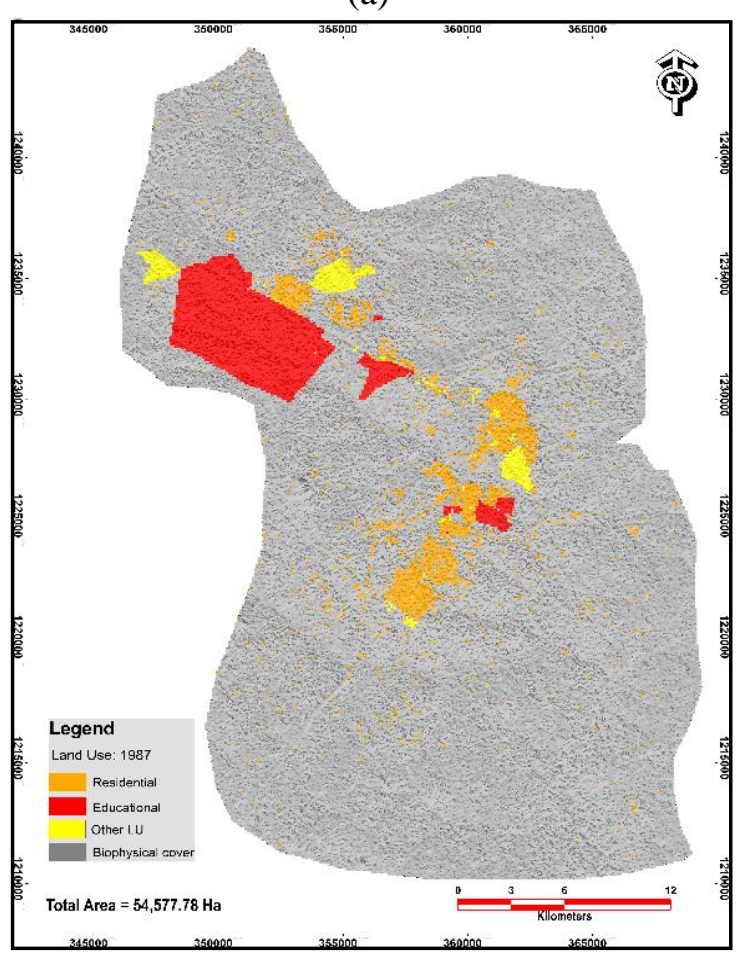

(c)

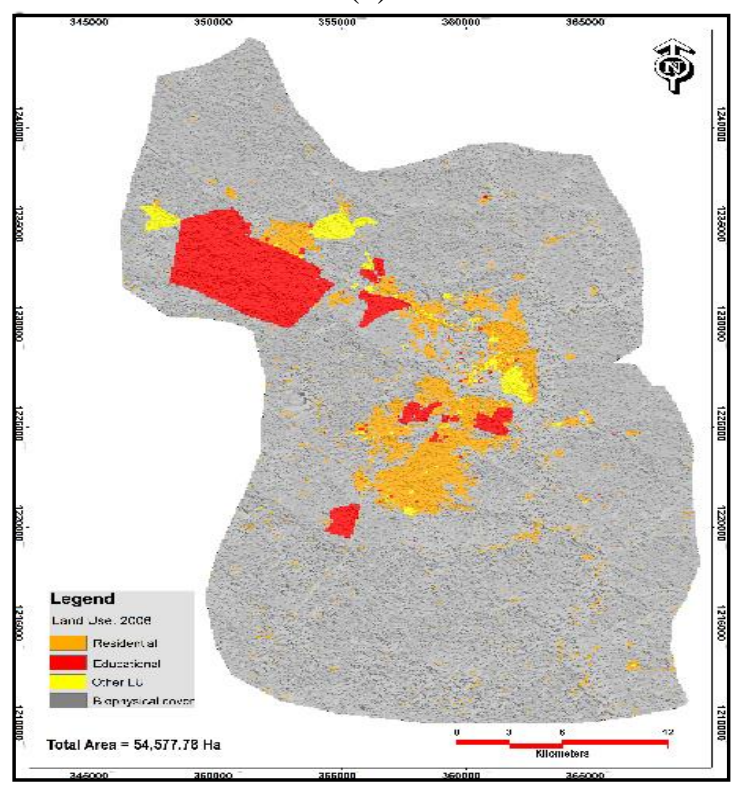

(b)

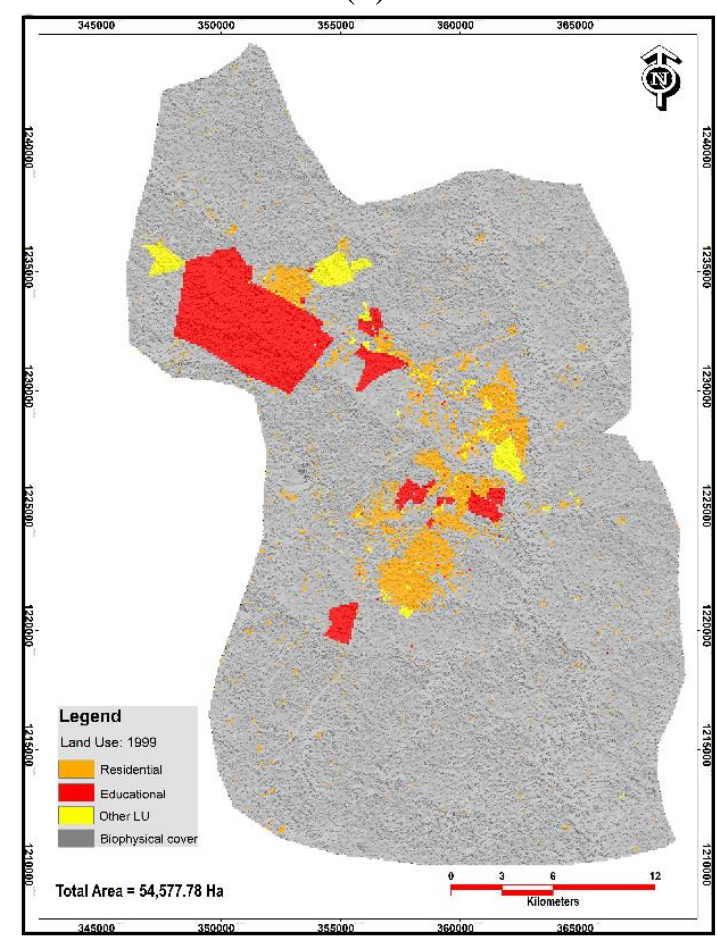

(d)

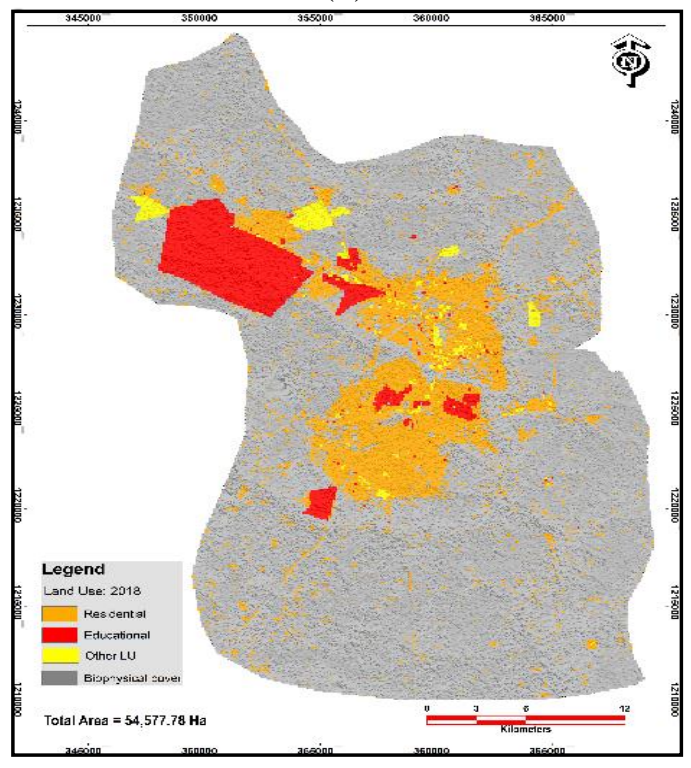

Figure 4: Classified maps of LC in Zaria and Sabon Gari (a) 1987 (b) 1999 (c) 2006 (d) 2018 


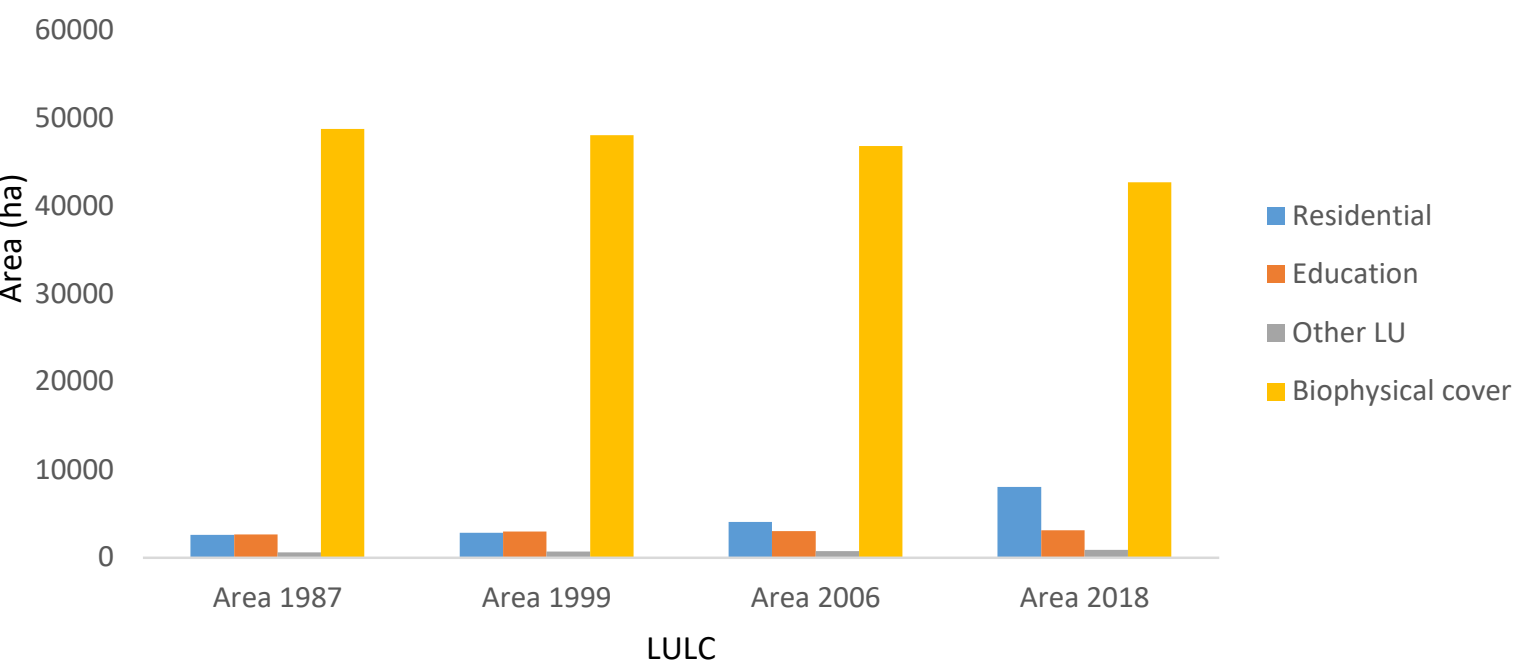

Figure 5: Area distribution of LUs of Zaria and Sabon Gari in 1987, 1999, 2006 and 2018

Table 4: Area percentage and change in area percentage LULC maps for 1987, 1999, 2006 and 2018

\begin{tabular}{|c|c|c|c|c|c|c|c|c|}
\hline \multirow[b]{2}{*}{ Class } & \multicolumn{4}{|c|}{ Area Percentage } & \multicolumn{4}{|c|}{ Change in Area Percentage } \\
\hline & 1987 & 1999 & 2006 & 2018 & $1987-1999$ & $1999-2006$ & $2006-2018$ & $1987-2018$ \\
\hline & Area $(\%)$ & Area $(\%)$ & Area $(\%)$ & Area $(\%)$ & Area $(\%)$ & Area $(\%)$ & Area $(\%)$ & Area $(\%)$ \\
\hline Residential & 4.76 & 5.16 & 7.41 & 14.69 & 0.406 & 2.245 & 7.281 & 9.931 \\
\hline Education & 4.81 & 5.48 & 5.53 & 5.66 & 0.676 & 0.050 & 0.122 & 0.847 \\
\hline Other LU & 1.06 & 1.25 & 1.34 & 1.60 & 0.186 & 0.089 & 0.263 & 0.539 \\
\hline Biophysical cover & 89.37 & 88.10 & 85.72 & 78.05 & -1.268 & -2.384 & -7.666 & -11.317 \\
\hline
\end{tabular}

\subsection{Land use change}

The changes in the residential and educational LUs are presented in Figure 6. It can be observed that the change in residential LU was 220.9 ha between 1987 and 1999, 1227.4 ha between 1999 and 2006, 3990.6 ha between 2006 and 2018, and 5438.9 ha between 1987 and 2018 respectively. For the educational LU, the change between 1987-1991 was 368.46 ha. It was 29.22 ha between 1999-2006. Between 2006-2018 and 1987-2018 were 72.65 ha and 470.34 ha respectively. Other LUs increased too overtime, but the biophysical cover decreased. It signified that the LUs increased with decrease in the biophysical cover. 
(a)

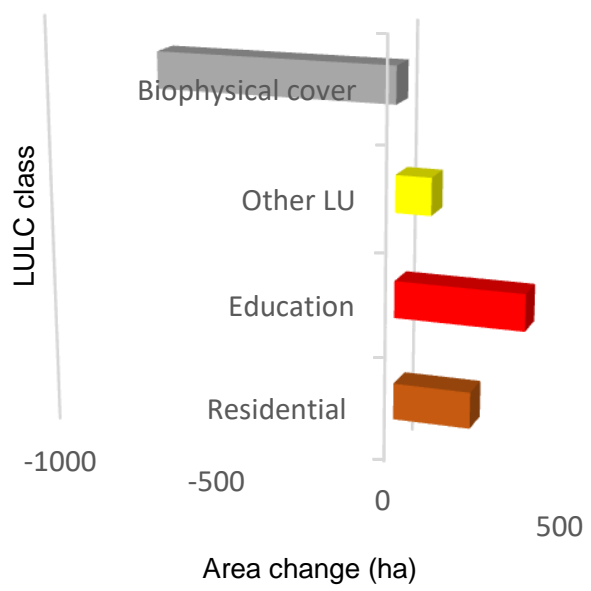

(c)

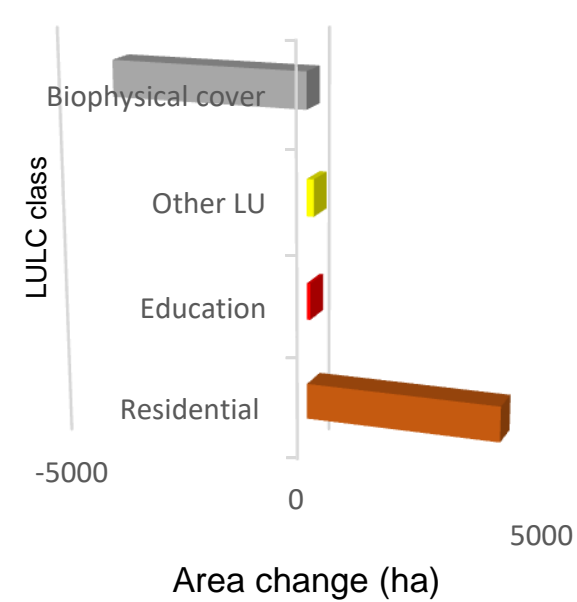

(b)

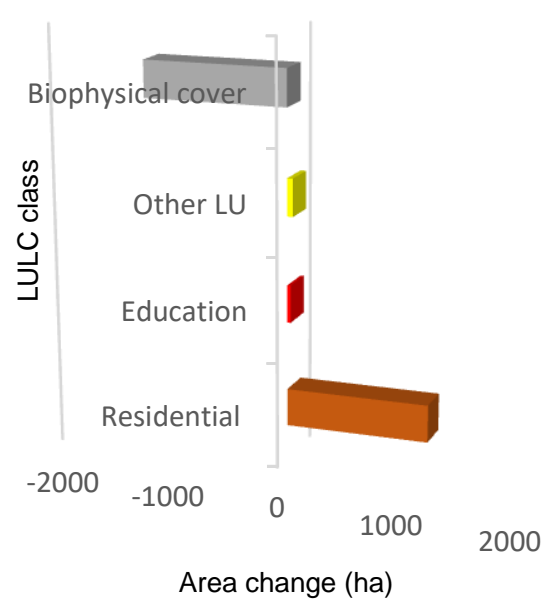

(d)

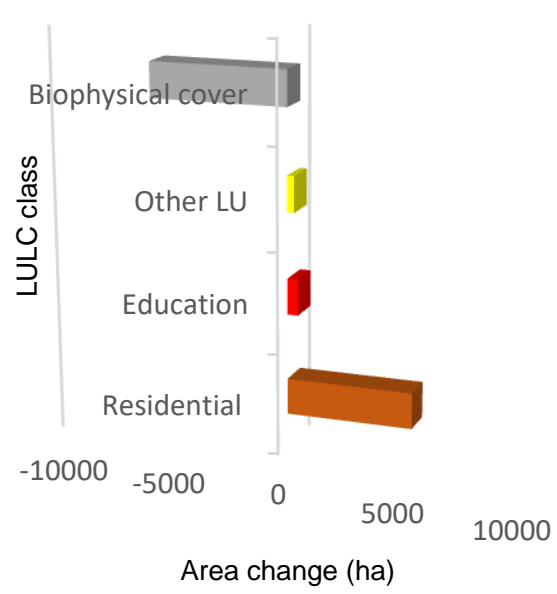

Figure 7: LULC area change: (a) 1987-1999, (b) 1999-2006, (c) 2006-2018, and (d) 1987-2018.

\subsection{Land absorption coefficient/land consumption rate}

The projected population estimates of Zaria Sabon Gari for the year 1987, 1999, 2006 and 2018 were computed as 467296, 602012, 698348, and 1000998 respectively (Tables 5 and 6). The population figures were interpolated using a growth rate of $3 \%$ as reported by the National Population Commission (2006) and the baseline population of 1999 and 2006. The LCR and LAC values of the residential and educational LUs are presented in Tables 5 and 6.

The LCR values for residential LU were $0.555 \%, 0.468 \%, 0.579 \%$, and $0.803 \%$ for the years 1987 , 1999, 2006, and 2018. The LCR reduced from 1987 to 1999 and then increased from 1999 to 2018. This implied that the crowdedness of the LU increased over the period of the study. This is indicative that the rate at which lands were utilized for residential development was high. The crowdedness in the residential LU can be attributed to the population of the study area increased overtime. Also, the LCR values for educational LU were $0.561 \%, 0.497 \%, 0.433 \%$, and $0.309 \%$ for the years 1987,1999 , 2006, and 2018. Here, the LCR reduced across the period of study. This signified that the educational LU was decongested and as the population increased, more space was sought for educational LU but not crowded. However, this is contrary to the LCR of the residential LU. Since the LCR of residential LU decreased and increased further, the pattern of the LCR of this study agreed with the works of Olaleye et al. (2012), Laxmikant et al. (2012) and Nair and Prasad (2018), because they reported similar findings of decrease and increase in built-up areas in their respective study area. The increase 
in the LCR values from earlier to recent year of this study agreed with the works of Aliyu et al. (2019).

Furthermore, the LAC values for the residential LU between 1987-1999 were 0.00164, it was 0.01274 between 1999-2006, and it was 0.01319 between 2006-2018. The LAC values increased across the period of the study. This inferred that more lands were sought and exploited for residential LU. For the educational LU, the LAC values between 1987-1999, 1999-2006, and 2006-2018 were 0.00274, 0.00030 , and 0.00024 respectively. The LAC values reduced for the years of study. This also inferred that more lands were sought and exploited for educational LU. The exploitation of the new lands for residential and educational LUs could be as a result of the demographic and institutional drivers of LU. This can be further buttressed by the growth of population overtime in the study area. Also, the study area is endowed with various types of institutions that attract all kinds of people from everywhere to want to come for studies and employments. Therefore, the population is bound to grow and demand and expansion of residential LU is inevitable.

The overall LAC values for residential and educational between 1987-2018 were 0.01019 and 0.00088. Comparatively, they are lower than the overall LAC value (0.0504) for Ilorin Emirate, Kwara state of Nigeria for a period of 1986-2006 as reported by Olaleye et al. (2012). In addition, the LAC of this study was lower than the overall LAC (0.013) of Ile-Ife city, Osun state of Nigeria for a period of 1986-2009 as reported by Oloukoi et al. (2014). These studies focused on the LAC of builtup as a whole, while this present study focused on the residential and educational LUs. Thus, the pattern of the LCR and LAC agrees with studies available in this subject area.

Table 5: LCR of the residential and educational LUs of the period of study

\begin{tabular}{llllllll}
\hline S/No & Year & $\begin{array}{l}\text { Residential } \\
\text { (ha) }\end{array}$ & $\begin{array}{c}\text { Area } \\
\text { (ha) }\end{array}$ & $\begin{array}{l}\text { Educational Area } \\
\text { Population }\end{array}$ & $\begin{array}{l}\text { Residential LCR } \\
(\%)\end{array}$ & $\begin{array}{l}\text { Educational LCR } \\
(\%)\end{array}$ \\
\hline 1 & 1987 & 2594.25 & 2623.41 & 467296 & 0.555 & 0.561 \\
2 & 1999 & 2815.15 & 2991.87 & 602012 & 0.468 & 0.497 \\
3 & 2006 & 4042.54 & 3021.10 & 698348 & 0.579 & 0.433 \\
4 & 2018 & 8033.19 & 3093.75 & 1000998 & 0.803 & 0.309 \\
\hline
\end{tabular}

Table 6: LAC of the residential and educational LUs of the period of study

\begin{tabular}{|c|c|c|c|c|c|c|}
\hline S/No & Year & $\begin{array}{ll}\text { Residential Area } \\
\text { Change (ha) }\end{array}$ & $\begin{array}{l}\text { Educational Area } \\
\text { Change (ha) }\end{array}$ & $\begin{array}{l}\text { Population } \\
\text { Change }\end{array}$ & $\begin{array}{l}\text { Residential } \\
\text { LAC }\end{array}$ & $\begin{array}{l}\text { Educational } \\
\text { LAC }\end{array}$ \\
\hline 1 & $\begin{array}{l}1987- \\
1999 \\
1999-\end{array}$ & 220.90 & 368.46 & 134716 & 0.00164 & 0.00274 \\
\hline 2 & 2006 & 1227.39 & 29.23 & 96336 & 0.01274 & 0.00030 \\
\hline 3 & $\begin{array}{l}2018 \\
1987-\end{array}$ & 3990.65 & 72.65 & 302650 & 0.01319 & 0.00024 \\
\hline 4 & 2018 & 5438.94 & 470.34 & 533702 & 0.01019 & 0.00088 \\
\hline
\end{tabular}

\subsection{Conclusions}

This study has assessed the consumption and absorption of the residential and educational land uses of Zaria and Sabon Gari local government areas of Kaduna state in Nigeria. The study utilized an integrated method of image classification for the identification of the residential and educational LUs and biophysical covers. The study analyzed Landsat datasets for the period of study was from 1987, 1999, 2006 to 2018 together with population data of 1991 and 2006, which were estimated for the years of study. The area distribution of the residential and educational LUs increased for the period of study. The study revealed that crowdedness of the residential LU increased over the period of the study. This is indicative that the rate at which lands were utilized for residential development was high. The crowdedness in the residential LU can therefore be attributed to population increase since the population of the study area increased overtime. The educational LU was not congested, and as the population increased, more space was sought for educational LU but not crowded. In addition, based on the LAC values, more lands were sought and exploited for residential LU. It revealed also that more lands were sought and exploited for educational LU. 
The findings of this study would serve as an important information to decision-makers in the management of land resources in the study area. Based on the findings of the study, it was suggested that the urban planning authority should develop planning measures that will regulate the already crowded residential LU in the Zaria and Sabon Gari LGAs of Kaduna state. In addition, the planning authority should ensure that the population does not surpass the existing educational facilities.

\section{Conflict of Interest}

There is no conflict of interest among the authors.

\section{Acknowledgements}

The authors acknowledged the United States Geological Survey (USGS) for the provision of the Landsat 8 OLI and TIRS utilized for classification for this study. Our appreciation to the remarkable efforts of the anonymous reviewers that aided in improving the comprehensiveness of this report.

\section{References}

Aliyu, Y. A., Youngu, T. T., Abubakar, A. Z., Bala, A. and Jesulowo, C. I. (2020). Monitoring and forecasting spatio-temporal LULC for Akure rainforest habitat in Nigeria. Reports on Geodesy and Geoinformatics, Sciendo, 110, pp. 29-38.

Anderson, J. (2008). A comparison of four change detection techniques for two urban areas in the United States. [Master Thesis, West Virginia University]. Retrieved from: maxwellsci.com/print/rjees/v5-567-576.pdf. Downloaded on: 16 September, 2017.

Anwar, S. M. (2002). Land use change dynamics: A dynamic spatial simulation. [Master Thesis Asian Institute of Technology School of Advanced Technologies Thailand]. Retrieved from: http://citeseerx.ist.psu.edu.

Aspinalls, R. J. and Hill, M. J. (2008). Land use change, science policy and management. New York CRC Press, Taylor and Francis Group.

Beckerman, W. (1992). Economic growth and the environment: whose growth? whose environment? World Dev. 20, pp. 481-496.

deBie, C. A., van Leeuwen, J. A. and Zuidema, P. A. (1996). The Land use database. a knowledgebased software programme for structure storage and retrieval of use-defined land use dataset. users' reference manual (v104, DOS). ITC, Enschede; FAO, Rome: Agricultural University, Wageningen.

Global Administrative Digital Map (GADM) (2018). Shapefiles of Nigeria states and local government areas. Retrieved from: https://gadm.org/download_country_v3.html. Downloaded on: 4 July, 2019.

GISGeography (2021). Object-based image analysis (GEOBIA). Retrieved from: https://gisgeography.com/obia-object-based-image-analysis-geobia/. Accessed on: 28 September, 2021.

Foody, G. M. and Atkinson, P. M. (2002). Uncertainty in remote sensing and GIS. John Wiley and Sons, London.

Karsidi, A. (2004). Spatial analysis of land use/land cover change dynamics using remote sensing and geographic information system: a case study in the downstream and surroundings of the Ci Tarum watershed. [Doctoral thesis - Department of Geographical and Environment Studies, the University of Adelaide, South Australia]. 
Kindu, M., Schneider, T., Teketay, D. and Knoke, T. (2013). Land use/land cover change analysis using object-based classification approach in Munessa-Shashemene landscape of the Ethiopian highlands. Remote Sens., 5, pp. 2411-2435.

Lambin, E.F. and Geist, H. J. (2001). Global land-use and land-cover change: What have we learned so far? Global Change Newslett. 46, pp. 27-30.

Laxmikant, S., Pandey, P. C. and Nathawat, M. S. (2012). Assessment of land consumption rate with urban dynamics change using geospatial techniques. J. Land Use Sci. 7(2), pp. 135-148.

Mather, A. S. (1986). Land Use. Longman, New York.

Nair, S. and Prasad, R. C. (2018). Assessing the impact of land use and land cover changes on the remnant patches of Kondapalli reserve forest of the Eastern Ghats, Andhra Pradesh, India. Egyptian Journal of Remote Sensing and Space Science, 419-429. DOI: 10.1016/j.ejrs.2018.01.00.

National Population Commission (NPC) (2006). National Population Commission: Nigerian Population Census Reports. Retrieved from: http://www.population.gov.ng. Downloaded on: 23 July, 2016.

Olaleye, J. B., Abiodun, O. E. and Asonibare, R. O. (2012). Land-use and land-cover analysis of Ilorin Emirate between 1986 and 2006 using Landsat imageries. African Journal of Environmental Science and Technology, 6(4), pp. 189-198. DOI: 10.5897/AJEST11.145.

Oloukoi, J., Oyinloye, R. O. and Yadjemi, H. (2014). Geospatial analysis of urban sprawl in Ile-Ife city, Nigeria. South African Journal of Geomatics, 3(2). DOI: http://dx.doi.org/10.4314/sajg.v3i2.2.

Ongsomwang, S. (2007). Fundamental of remote sensing and digital image processing. School of remote sensing, institute of science, Suranaree University of Technology.

Ouedraogo, I. (2010). Land use dynamics and demographic change in southern Burkina Faso. [Doctoral thesis - Swedish university of agricultural sciences Alnarp]. Retrieved from: https://pub.epsilon.slu.se > Ouedrago_I_100928.

Prasad, R. C. P., Rajan, K. S., Dutt, C. B. S. and Roy, P. S. (2010). A conceptual framework to analyze the land-use/land-cover changes and its impact on phyto-diversity - a case study of North Andaman Islands India. Biodiversity Conservation, 19(11), pp. 3073- 3087.

Rimal, B., Sloan, S., Keshtkar, H., Sharma, R., Rijal, S., and Shrestha, U. B. (2020). Patterns of historical and future urban expansion in Nepal. Remote Sensing, 12 (4):628, doi:10.3390/rs12040628.

Rindfuss, R. R., Walsh, S. J., Turner, B. L., Fox, J. and Mishra, V. (2004). Developing a science of land change: challenges and methodological issues. Proceedings of the National Academy of Sciences of the United States of America, 101, pp. 13976-13981.

Skole, D. and Tucker, C. (1993). Tropical deforestation and habitat fragmentation in the amazon: satellite data from 1978 to 1998. Science, 260, pp. 1905-1910.

Tsvetkova, O. (2007). Spatial and temporal dynamics of land use impacts on water quality in watershed systems. (Masters Theses - University of Massachusetts Amherst). Retrieved from: https://scholarworks.umass.edu/theses/67

Turner, B. L. and Robbins, P. (2008). Land-change science and political ecology: similarities, differences, and implications for sustainability science. Annual Review of Environment and Resources, 33, pp. 295-316. 
Turner, B. L., Lambin, E. F. and Reenberg, A. (2007). The emergence of land change science for global environmental change and sustainability. Proceedings of the National Academy of Sciences of the United States of America, 104, pp. 20666-20671.

United State Geological Survey (USGS) (2013). Landsat. Retrieved from: http://www.landsat.usgs.gov. Downloaded on: 3 December, 2013.

Verburg, P. (2000). Exploring the spatial and temporal dynamics of land use with special reference to China. Retrieved from: https://edepot.wur.nl.

Wondie, M., Schneider, W., Melesse, A.M. and Teketay, D. (2011), Spatial and temporal land cover changes in the simen mountains national park, a world heritage site in north western Ethiopia. Remote Sens. 3, pp. 752-766.

Yeates, M. and Garner, B. (1976). The North American city, Harper and Row Pub. New York.

\section{Cite this article as:}

Sule J. O., Ojigi L. M., Adewuyi T. O., Azua S., Aliyu A. O. and Akomolafe E. O., 2021. Geospatial Assessment of the Consumption and Absorption of Residential and Educational Land Uses of Zaria and Sabon Gari Area of Kaduna State, Nigeria. Nigerian Journal of Environmental Sciences and Technology, 5(2), pp. 476-489. https://doi.org/10.36263/nijest.2021.02.0299 